\title{
COMPARISON OF CALCIUM HYDROXIDE AND CHLORHEXIDINE GEL AS INTRACANAL MEDICAMENT IN RELIEVING INTERAPPOINTMENT PAIN: EFFECT OF GENDER AND AGE.
}

\footnotetext{
1. FCPS, BDS

Assistant Professor Operative

Dentistry

Lahore Medical and Dental College,

Lahore.

2. FCPS, BDS

Associate Professor Operative

Dentistry

FMH College of Medicine and

Dentistry, Lahore.

3. FCPS, BDS

Assistant Professor Prosthodontics

Lahore Medical and Dental College, Lahore.
}

Correspondence Address:

Dr. Anam Fayyaz Bashir

Assistant Professor Operative Dentistry

Medical and Dental College, Lahore.

anam.fayyaz@Imdc.edu.pk

Article received on:

18/09/2019

Accepted for publication:

$20 / 01 / 2020$

\section{Anam Fayyaz Bashir ${ }^{1}$, Saroosh Ehsan ${ }^{2}$, Ussamah Waheed Jatala ${ }^{3}$}

ABSTRACT... Objectives: This study was done to compare calcium hydroxide $\left(\mathrm{Ca}(\mathrm{OH})_{2}\right)$ and chlorhexidine (CHX) in relieving interappointment pain, in addition to observe influence of gender and age. Study Design: Randomized Control trial. Setting: Department of Operative Dentistry, Fatima Memorial Hospital, Lahore. Period: $3^{\text {rd }}$ October 2016 to $20^{\text {th }}$ May 2017. Material \& Methods: 100 subjects were divided into 2 groups of 50, group $A\left(\mathrm{Ca}(\mathrm{OH})_{2}\right)$ and group $\mathrm{B}(\mathrm{CHX})$. Information was recorded regarding the gender, age, intracanal medicament used, VAS pain scores of preoperative pain at 24 hours, 48 hours and on the $4^{\text {th }}$ day of placing medicament. Change in pain scores was assessed as the main outcome variable. Results: VAS score mean difference for both medicaments was significant for 24 hours, 48 hours and $4^{\text {th }}$ day $\left(p<0.0005\right.$. $\mathrm{CHX}$ medicament decreased pain more as compared to $\mathrm{Ca}(\mathrm{OH})_{2}$. Age had no significant effect on VAS score decrease but females had significant decrease in pain $(p=0.04)$. Conclusion: $\mathrm{CHX}$ decreased the mean interappointment pain score more as compared to $\mathrm{Ca}(\mathrm{OH})_{2}$

Key words:

Calcium Hydroxide, Chlorhexidine, Interappointment Pain, Visual Analogue Scale.

Article Citation: Bashir AF, Ehsan S, Jatala UW. Comparison of calcium hydroxide and chlorhexidine gel as intracanal medicament in relieving interappointment pain: Effect of gender and age. Professional Med J 2020; 27(9):1878-1884. DOI: 10.29309/TPMJ/2020.27.09.4175

\section{INTRODUCTION}

Odontogenic pain is the most commonly observed reason for a patient to seek dental treatment. Ironically dental pain itself may be a reason for the patient to leave the dental office if the dentist fails to resolve the complaint. Therefore, a dental clinician always attempts to advocate those treatment modalities that relieve pain efficiently.

Endodontic pain occurs due to dental caries, necrotic pulp, trauma and infection after any post-operative procedure. ${ }^{1,2}$ It may occur before treatment, during treatment and/or after tooth is root canal treated. Interappointment pain occurs due to inflammation of periradicular tissues. The causative agent typically is bacterial, but can be chemical and/or mechanical in nature. Some factors such as age, gender, tooth type and presence of preoperative pain have been observed to influence the development of interappointment pain. ${ }^{3}$ The rationale behind intracanal medication is to terminate residual microbes and their toxins and any residual bacteria that have not been removed during chemomechanical preparation. ${ }^{4}$ The medicament should inhibit microbial recolonization of the debrided parts of the root canal system by inhibiting residual microorganisms from growing and new microorganisms from invading through the lateral communications within the canal and coronal access of tooth. ${ }^{5}$

When Hermann introduced $\mathrm{Ca}(\mathrm{OH})_{2}$ in 1920 , it revolutionized pulp therapy. It is a white odorless powder, $12.5 \mathrm{pH}$, has low solubility in water which decreases as temperature rises and is insoluble in alcohol. ${ }^{6}$ In presence of water it dissociates into calcium and hydroxyl ions. The aforementioned properties are largely due to its alkaline $\mathrm{pH}$ and due to these hydroxyl ions. It also has tissue dissolving ability which is useful when inadvertent pulpal tissue is left behind in root after chemomechanical preparation. ${ }^{7}$

Chlorhexidine is a strong cationic bisguanide 
molecule, hydrophobic and lipophilic in nature. ${ }^{8}$ $\mathrm{CHX}$ has a wide range of antibacterial activity including gram positive and gram negative bacteria, facultative aerobes and anaerobes, yeasts and fungi especially Candida. It is active against some viruses as well such as herpes, HIV, cytomegalovirus etc. At a low concentration, of $0.2 \%$, low molecular weight substances like phosphorous and potassium seep out of cell wall. ${ }^{9}$ At high concentration of $2 \%$, CHX kills microbes by causing precipitation in the cytoplasm and/or coagulation by causing cross linkage in proteins. Substantivity of $\mathrm{CHX}$ is exponentially time related i.e. amount of the molecule release increases directly proportionally to the application time. Komorowski et al demonstrated that a 5 min application of $\mathrm{CHX}$ was not sufficient to induce substantivity and advocated placing $\mathrm{CHX}$ in canal for 7 days. ${ }^{10}$

The rationale of this research was to compare relief of interappointment pain by using calcium hydroxide and chlorhexidine gel, two of the most widely used intracanal medicaments available. Effect of age and gender on decrease in pain was to be observed too. Achieving pain relief by simply placing a medicament inside the tooth would drastically increase patient comfort and compliance.

\section{MATERIAL \& METHODS}

This study was conducted in the department of Operative Dentistry in Fatima Memorial Hospital, after taking approval from the ethical committee (IRB) of FMH College. Single rooted teeth with apical periodontitis, not requiring incision and drainage, with pre endodontic pain of VAS ranging from 4-8 for 2 weeks or less, aged 15 to 60 , were included in the study. Teeth with incomplete root formation and severe periodontal problems and patients suffering from systemic diseases e.g. diabetes and autoimmune disease etc were excluded from the study. An informed consent was taken from every patient ensuring confidentiality of their data which was recorded in a specially designed proforma. The presenting symptom of pain was assessed by using the visual analogue scale (VAS). After confirmation of diagnosis an established protocol was followed for all patients for access opening, cleaning and shaping of root canals, using crown down technique. Subjects were then divided into two groups on random allocation basis to control bias, by lottery method. 100 patients were included that were divided into two groups by lottery method: Group A had calcium hydroxide as intracanal medicament and group B had chlorhexidine gel. Intracanal medications were inserted into dried canals with lentulo spirals. Access cavities were sealed with cavit. Pain score was assessed on the VAS at the start of the treatment (preoperatively) appointment at 24 hours, 48 hours and on the 4th day after placing the intracanal medicament. Change in VAS scores was assessed as the main outcome variable. The sample size was calculated using $95 \%$ confidence level, $80 \%$ power of test with expected mean interappointment pain as $21.1 \pm 5$ in calcium hydroxide and $14.6 \pm$ 2.52 in chlorhexidine group as 100 (50 each). ${ }^{11}$ No antibiotics were prescribed. Patients were requested to stop taking analgesics except if pain persisted or recurred.

Data collected was entered in SPSS version 20 and analyzed. The qualitative data was presented in the form of frequency and percentages for gender. The quantitative data was presented in the form of mean and standard deviation for age and VAS ratings. Pain being measured by VAS rating was tested by repeated measure ANOVA test among groups at preoperative pain, 24 hours, 48 hours and 4 days post treatment. Post stratification ANOVA test was used, to compare the results with $p$-value of 0.05 or less as significant.

\section{RESULTS}

One hundred teeth were treated in the study. No patient dropped out of the study. Out of these 100 subjects, 39 were males whereas 61 were females. Amongst males, those with $\mathrm{Ca}(\mathrm{OH})_{2}$ were 20 (51.28\%) and 19 (48.72\%) had $\mathrm{CHX}$ in their teeth respectively, whereas 30 (49.18\%) female patients had $\mathrm{Ca}(\mathrm{OH})_{2}$ and 31 (50.82\%) had $\mathrm{CHX}$. The mean age of the patients was 36.67 \pm 13.51 . 38. Patients had age range from 15-30 whereas 31-60 age category had 62 patients. Table-I shows mean and standard deviation. 


\begin{tabular}{|l|c|}
\hline \multicolumn{1}{|c|}{ Variable } & Mean \pm S.D. \\
\hline Age & $36.67 \pm 13.504$ \\
\hline $\begin{array}{l}\text { VAS Preoperative Score } \\
\text { (for both groups) }\end{array}$ & $7.7900 \pm 1.49271$ \\
\hline $\begin{array}{l}\text { VAS 24 hour score } \\
\text { (for both groups) }\end{array}$ & $2.8200 \pm 1.85527$ \\
\hline $\begin{array}{l}\text { VAS 48 hour score } \\
\text { (for both groups) }\end{array}$ & $0.8100 \pm 1.19507$ \\
\hline $\begin{array}{l}\text { VAS 4 days score } \\
\text { (for both groups) }\end{array}$ & $0.2600 \pm 0.74698$ \\
\hline $\begin{array}{l}\text { VAS Preoperative Score } \\
\text { (for Group A) }\end{array}$ & $7.7600 \pm 1.63582$ \\
\hline \begin{tabular}{l} 
VAS 24 hour score (for Group A) \\
\hline VAS 48 hour score (for Group A)
\end{tabular} & $3.2200 \pm 2.03329$ \\
\hline \begin{tabular}{l} 
VAS 4 days score (for Group A) \\
\hline $\begin{array}{l}\text { VAS Preoperative Score } \\
\text { (for Group B) }\end{array}$
\end{tabular} & $0.48000 \pm 0.99468$ \\
\hline VAS 24 hour score (for Group B) & $2.4200 \pm 1.57907$ \\
\hline $\begin{array}{l}\text { VAS 48 hour score (for Group B) } \\
\text { Table-I. Mean and standard deviation for Age and }\end{array}$ & $0.5200 \pm 0.95276$ \\
\hline $\begin{array}{l}\text { VAS } 4 \text { days score (for Group B) } \\
\text { VAS scores. }\end{array}$ & $0.0400 \pm 0.19795$ \\
\hline
\end{tabular}

Post hoc ANOVA tests revealed that interappointment pain VAS score decreased from preoperative time to 24 hours, 48 hours and 4 days, were all statistically significant ( $p$ $=0.0005)$. The mean difference in VAS score from preoperative time to $4^{\text {th }}$ day for $\mathrm{Ca}(\mathrm{OH}) 2$ group was 7.28 whereas for $\mathrm{CHX}$ it was 7.78. Therefore, we can conclude that both intracanal medicaments elicited a statistically significant reduction in interappointment pain since their placement till day 4 .

Table-Il shows descriptive statistics of age in both medicament groups with VAS score. No statistical significant relation was observed between medicament, age and VAS score.

Table-III shows descriptive statistics of gender with medicament groups and VAS score. No statistical significance was found between groups, male and decrease in VAS score but interestingly there was significant decrease in females when all three components were related $(p=0.04)$.

\begin{tabular}{|c|c|c|c|c|}
\hline \multicolumn{2}{|c|}{ Age } & Medicament group & Mean & Std. Deviation \\
\hline \multirow{12}{*}{$15-30$} & \multirow{3}{*}{ Preoperative pain } & $\mathrm{Ca}(\mathrm{OH}) 2$ & 7.8824 & 1.53632 \\
\hline & & $\mathrm{CHX}$ & 7.9048 & 1.26114 \\
\hline & & Total & 7.8947 & 1.37132 \\
\hline & \multirow{3}{*}{ pain after 24 hours } & $\mathrm{Ca}(\mathrm{OH}) 2$ & 3.5294 & 2.21127 \\
\hline & & $\mathrm{CHX}$ & 2.6667 & 1.68325 \\
\hline & & Total & 3.0526 & 1.95831 \\
\hline & \multirow{3}{*}{ pain after 48 hours } & $\mathrm{Ca}(\mathrm{OH}) 2$ & 1.0588 & 1.29762 \\
\hline & & $\mathrm{CHX}$ & 0.7143 & 1.18924 \\
\hline & & Total & 0.8684 & 1.23400 \\
\hline & \multirow{3}{*}{ pain after 4 days } & $\mathrm{Ca}(\mathrm{OH}) 2$ & 0.5294 & 1.17886 \\
\hline & & $\mathrm{CHX}$ & 0.0000 & 0.00000 \\
\hline & & Total & 0.2368 & 0.81983 \\
\hline \multirow{12}{*}{$31-60$} & \multirow{3}{*}{ Preoperative pain } & $\mathrm{Ca}(\mathrm{OH}) 2$ & 7.6970 & 1.70449 \\
\hline & & $\mathrm{CHX}$ & 7.7586 & 1.43066 \\
\hline & & Total & 7.7258 & 1.56989 \\
\hline & \multirow{3}{*}{ pain after 24 hours } & $\mathrm{Ca}(\mathrm{OH}) 2$ & 3.0606 & 1.95159 \\
\hline & & $\mathrm{CHX}$ & 2.2414 & 1.50369 \\
\hline & & Total & 2.6774 & 1.79045 \\
\hline & \multirow{3}{*}{ pain after 48 hours } & $\mathrm{Ca}(\mathrm{OH}) 2$ & 1.1212 & 1.38649 \\
\hline & & $\mathrm{CHX}$ & 0.3793 & 0.72771 \\
\hline & & Total & 0.7742 & 1.17932 \\
\hline & \multirow{3}{*}{ pain after 4 days } & $\mathrm{Ca}(\mathrm{OH}) 2$ & 0.4545 & 0.90453 \\
\hline & & $\mathrm{CHX}$ & 0.0690 & 0.25788 \\
\hline & & Total & 0.2742 & 0.70523 \\
\hline
\end{tabular}




\begin{tabular}{|c|c|c|c|c|}
\hline \multicolumn{2}{|c|}{ Sex } & Medicament Group & Mean & Std. Deviation \\
\hline \multirow{8}{*}{ Male } & \multirow[b]{2}{*}{ Preoperative pain } & $\mathrm{Ca}(\mathrm{OH}) 2$ & 7.6500 & 1.72520 \\
\hline & & $\mathrm{CHX}$ & 7.7895 & 1.61861 \\
\hline & \multirow[b]{2}{*}{ pain after 24 hours } & $\mathrm{Ca}(\mathrm{OH}) 2$ & 3.1000 & 2.35975 \\
\hline & & $\mathrm{CHX}$ & 2.3158 & 1.52944 \\
\hline & \multirow{3}{*}{ pain after 48 hours } & $\mathrm{Ca}(\mathrm{OH}) 2$ & 0.9500 & 1.27630 \\
\hline & & $\mathrm{CHX}$ & 0.3158 & .67104 \\
\hline & & Total & 0.6410 & 1.06344 \\
\hline & pain after 4 days & $\mathrm{Ca}(\mathrm{OH}) 2$ & 0.4500 & 1.09904 \\
\hline \multirow{8}{*}{ Female } & \multirow[t]{2}{*}{ Preoperative pain } & $\mathrm{CHX}$ & 7.8387 & 1.18594 \\
\hline & & Total & 7.8361 & 1.39260 \\
\hline & \multirow{3}{*}{ pain after 24 hours } & $\mathrm{Ca}(\mathrm{OH}) 2$ & 3.3000 & 1.82228 \\
\hline & & $\mathrm{CHX}$ & 2.4839 & 1.63036 \\
\hline & & Total & 2.8852 & 1.76161 \\
\hline & \multirow{3}{*}{ pain after 48 hours } & $\mathrm{Ca}(\mathrm{OH}) 2$ & 1.2000 & 1.39951 \\
\hline & & $\mathrm{CHX}$ & 0.6452 & 1.08162 \\
\hline & & Total & 0.9180 & 1.26879 \\
\hline
\end{tabular}

Table-III. Post Stratification ANOVA - VAS score with gender.

\section{DISCUSSION}

In this study, crown down method of canal preparation was used. This method of preparation compared to others causes less extrusion of debris in the periapical area as this extruded debris may influence inflammatory response of the periapical tissues. ${ }^{12}$ This method also leads to better debrided walls as canal is widened in an apical direction thereby enhancing needle irrigation, and canal contents are removed coronally.

Weiger et al demonstrated that $\mathrm{E}$. faecalis in an infected tooth was not affected by $\mathrm{Ca}(\mathrm{OH})_{2} \cdot{ }^{13} \mathrm{It}$ was found that $\mathrm{Ca}(\mathrm{OH})_{2}$ did not act effectively against Candida species most probably due to the fact that they are more resistant to $\mathrm{pH}$ changes in the environment. ${ }^{6}$ On the contrary, $\mathrm{Ca}(\mathrm{OH})_{2}$ provides Candida with calcium ions that aid in fungal growth. ${ }^{14}$ To overcome this disadvantage of $\mathrm{Ca}(\mathrm{OH})_{2}$, it can be used in combination with chlorhexidine.

$\mathrm{CHX}$ has a wider antimicrobial spectrum yet not a complete spectrum that kills all spores. It is not effective against bacterial spores, mycobacteria and most viruses. ${ }^{15}$ Komorowski et al demonstrated that a mere 5-minute application of $\mathrm{CHX}$ did not cause substantivity in the tooth therefore they suggested a 7-day period for medicament placement in tooth. ${ }^{16}$

Al Zaka conducted a research in which he compared calcium hydroxide and chlorhexidine as intracanal medicaments. ${ }^{17} \mathrm{He}$ placed either medicament in a patients tooth and recorded pain at 4 hours, 24 hours and 48 hours. In his study he found significant decrease in pain $(p$ $<0.001$ ) with time in each group. And between groups of medicament, he found significant 
difference $(p<0.05)$ within 4 hours and 24 hours and no significant difference $(p>0.05)$ was found between groups after 48 hours. This result is in accordance to this study as decrease in pain was significant $(p<0.0005)$ from preoperative VAS score to 24 hours, 48 hours and $4^{\text {th }}$ day.

Singh et al used four groups to measure change in interappointment pain (IP) in 64 teeth, $\mathrm{Ca}(\mathrm{OH})_{2}$ combined with $\mathrm{CHX}$ group, $\mathrm{CHX}$ group, $\mathrm{Ca}(\mathrm{OH})_{2}$ group and no medicament group. ${ }^{11}$ They recorded readings at 4 hours, 24 hours, 48 hours, 72 hours and 96 hours. They demonstrated that the first 2 groups were significantly more effective in reducing IP $(p<0.05)$ than the latter 2 groups. They stated that the most likely reason for lower results for $\mathrm{Ca}(\mathrm{OH})_{2}$ was that even though $\mathrm{Ca}(\mathrm{OH})_{2}$ had adequate antibacterial properties, it failed to kill microbes within the canal and within dentinal tubules that lead to periapical inflammation.

A study was conducted by Quadir et al, on 465 patients, using $\mathrm{Ca}(\mathrm{OH})_{2}, \mathrm{CHX}$ and no medicament in 3 groups. ${ }^{18}$ Their results showed $\mathrm{CHX}$ to most effectively decrease pain as compared to the other groups ( $p<0.0005$ ), though their study took into account only a single reading at 72 hours. This is in accordance to this study where $p<0.0005$ when preoperative pain was compared to 48 hours and $4^{\text {th }}$ day scores. Quadir et al also reported that they observed a significant difference between post-operative pain when $\mathrm{CHX}$ was used as compared to $\mathrm{Ca}(\mathrm{OH})_{2}$. On the contrary, in this study both medicament caused a significant reduction in pain, with chlorhexidine giving a larger mean difference.

Ballal et al demonstrated in their research that $\mathrm{CHX}$ gel is more effective than $\mathrm{Ca}(\mathrm{OH})_{2}$ or their combination in their antibacterial action against Candida albicans and Enterococcus faecalis. ${ }^{19}$ Thus this may be the reason that $\mathrm{CHX}$ had a larger mean difference in VAS score change.

In this study, there was greater reduction in IP when $\mathrm{CHX}$ was used as compared to $\mathrm{Ca}(\mathrm{OH})_{2}$ with the greatest mean difference in VAS score occurring on the $4^{\text {th }}$ day, meaning that as long as the medicament had time to act on the microbial content of the canal, pain decreased. Its effect was measurable within 24 hours after placement in canal as time is needed for diffusion of medicament into dentinal tubules and periradicular tissues so as to act on microbes. An additional effect of $\mathrm{CHX}$ is that it has maintained substantivity thereby releasing $\mathrm{CHX}$ molecules from the adsorbed layer on the canal walls. Additionally, the initial mean pain scores recorded were higher for $\mathrm{CHX}$ group (7.8200 \pm 1.35059$)$ as compared to $\mathrm{Ca}(\mathrm{OH})_{2}(7.7600 \pm 1.63582)$.

Siqueira Jr et al stated that factors such as age, gender, tooth type and presence of preoperative pain were observed to influence the development of interappointment pain. ${ }^{4}$ Gender differences in pain have repeatedly revealed that females have a higher initial pain score reporting, along with a greater decrease in pain. ${ }^{20}$ This may be due to the fact that females report pain when they experience a high pain score as compared to males. ${ }^{21,22}$ In this study, the finding was that females had a significant decrease in VAS score as compared to males $(p=0.04)$. Female patients feel more pain

There are multiple factors that can play into the limitation of this study, the main being pain itself. Pain is subjective, therefore profound individual differences in sensitivity complicate its recording. Different patients have different thresholds to the same intensity of pain. In addition, a method is yet to be developed to objectify pain in a standardized method. Unless that occurs, visual analogue scale is an efficient manner to record patient pain.

\section{CONCLUSION}

The aim of a clinician is always to be empathetic towards a patient especially if he is in pain. All measures are taken by all clinicians to make the patient symptom free as soon as possible, causing the least inadvertent harm, by using the appropriate techniques and drugs. A patient made pain free would always be more compliant for further treatment whenever necessary.

$\mathrm{CHX}$ gel demonstrated better mean difference in decreasing VAS score, even though both 
medicaments showed significant decrease in pain. There was no influence of age on VAS scores and medicament but females demonstrated significant decrease in pain when using either medicament.

Copyright $(20$ Jan, 2020.

\section{REFERENCES}

1. Dall $A Q$, Jouhar R, Khoso NA. Comparison of InterAppointment Pain Between Ledermix and no Intracanal Medicament in Acute Apical Periodontitis. J Liaquat Uni Med Health Sciences 2011; 10:106-11.

2. Khattak O, Ahmed A, Shahnawaz A, Javed Q, Minhas $\mathrm{SA}$. Reasons for carrying root canal treatment-a study. Pak Oral Dent J 2009; 29:107-110.

3. Siqueira Jr JF, Lopes HP. Mechanisms of antimicrobial activity of calcium hydroxide: A critical review (Review). Int Endod J 2008; 32:361-9.

4. Memon NA, Memon MR, Ali F, Ane NU. Assessment of the interappointment pain by using two different intracanal medicaments. Pak Oral Dent J 2013; 33:145-50.

5. Bystrom A, Happonen RP, Sjogren U, Sundqvist G. Healing of periapical lesions of pulpless teeth after endodontic treatment with controlled asepsis. Endod Dent Trauma 1987; 3:58-63.

6. Mohammadi Z, Dummer PMH. Properties and applications of calcium hydroxide in endodontics and dental traumatology. Int Endod J 2011; 44:697730.

7. Bergenholtz G, Torneck C, Kishen A. Inter-appointment Medication with Calcium Hydroxide in Routine Cases of Root Canal Therapy. In: Paz LECD, Sedgley CM, Kishen A editors. The Root Canal Biofilm. New York: Springer; 2015. p. 303-26. (Springer Series on Biofilms; vol. 9).

8. Babar A, Ibrahim MW, Baig NJ, Shah I, Amin E. Efficacy of Intra-Alveolar Chlorhexidine Gel in Reducing Frequency of Alveolar Osteitis in Mandibular Third Molar Surgery. J Coll Phys Surg Pak 2012; 22:91-4.

9. Gomes BP, Souza SF, Ferraz CC, Teixeira FB, Zaia AA, Valdrighi $L$ et al. Effectiveness of $2 \%$ chlorhexidine gel and calcium hydroxide against Enterococcus faecalis in bovine root dentine in vitro. Inter Endod J 2003; 36:267-75.

10. Komorowski R, Grad H, Wu XY, Friedman S. Antimicrobial substantivity of chlorhexidine-treated bovine root dentine. J Endod 2000; 26:315-7.
11. Singh RD, Khatter R, Bal RK, Bal CS. Intracanal medications versus placebo in reducing postoperative endodontic pain - a double-blind randomized clinical trial. Brazil Dent J 2013; 24:25-9.

12. Siqueira Jr JF, Rocas IN. Intracanal medication. In: Chong BS editor. Harty's Endodontics in Clinical Practice. 7th ed. China: Elsevier Ltd; 2016:129-50.

13. Weiger R, De Lucena J, Decker HE, Lost C. Vitality status of microorganisms in infected human root dentine. Inter Endod J 2002; 35:166-71.

14. Siqueira JF, Sen BH. Fungi in endodontic infections. Oral Surg Oral Med Oral Path Oral Radio Endod 2004; 97:632-41.

15. Mohammadi Z, Abbott PV. Antimicrobial substantivity of root canal irrigants and medicaments: A review. Aust Endod J 2009; 35:131-9.

16. Komorowski R, Grad H, Wu XY, Friedman S. Antimicrobial substantivity of chlorhexidine-treated bovine root dentine. J Endod 2000; 26:315-7.

17. Al-Zaka IM. The incidence of post treatment pain using two different intracanal medicaments. Mustansiria Dent J 2007; 4:110-6.

18. Quadir F, Amin F, Shahbaz U. Comparison of intracanal medications for the assessment of pain after root canal treatment. Pak Oral Dent J 2015; 35:286-9.

19. Ballal V, Kundabala M, Acharya S, Ballal M. Antimicrobial action of calcium hydroxide, chlorhexidine and their combination on endodontic pathogens. Aust Dent $\mathrm{J}$ 2007; 52:118-21.

20. Unruh AM, Ritchie J, Merskey $H$. Does gender affect appraisal of pain and pain coping strategies? Clin $\mathrm{J}$ Pain. 1999; 15:31-40.

21. Dao T, Leresche L. Gender differences in pain. $J$ Orofac Pain. 2000; 14:169-84.

22. Walton RE. Interappointment flare-ups: Incidence, related factors, prevention, and management. Endod Topics. 2002; 3:67-76.

23. Siqueira JF Jr, Barnett F. Interappointment pain: Mechanisms, diagnosis, and treatment. Endod Topics. 2004; 7:93-109. 


\section{AUTHORSHIP AND CONTRIBUTION DECLARATION}

\begin{tabular}{|l|l|l|}
\hline Sr. \# & Author(s) Full Name & \multicolumn{1}{c|}{ Contribution to the paper } \\
\hline 1 & Anam Fayyaz Bashir & $\begin{array}{l}\text { Conception of idea, acquisition, analysis and } \\
\text { interpretation of data for the work. Drafting of } \\
\text { the work and revising it critically for important } \\
\text { intellectual content. Final approval of the version } \\
\text { to published. Agreement to be accountable for } \\
\text { all aspects of the work in ensuring that questions } \\
\text { related the the accuracy or integrity of anay part the the } \\
\text { work are appropriately investigated and resolved. }\end{array}$ \\
2 & Saroosh Ehsan & $\begin{array}{l}\text { Revising manuscript critically for important content, } \\
\text { Final approval of the version to be published. } \\
\text { Agreement to be accountable for all aspects of } \\
\text { the work in ensuring that questions related to the } \\
\text { accuracy or integrity of anay part of the work are } \\
\text { appropriately investigated and resolved. }\end{array}$ \\
3 & Ussamah Waheed Jatala & $\begin{array}{l}\text { Drafting of the work, Final approval of the version } \\
\text { of be published. Agreement to be accountable for } \\
\text { all aspects of the work in ensuring that questions } \\
\text { related to the accuracy or integrity of anay part of the } \\
\text { work are appropriately investigated and resolved. }\end{array}$ \\
\hline
\end{tabular}

